Journal of Jungian Scholarly Studies

Vol. 3, No. 6, 2007

\title{
Why Hillman Matters
}

Bernie Neville, Ph.D.

La Trobe University, Australia

This paper is an acknowledgement of the intellectual debt that the author owes to James Hillman. Just how significant a figure Hillman has been in Jungian studies may not be clear for some time, but for myself as a Jung-oriented academic Hillman's ideas have had exceptional personal as well as professional resonance, introducing me to a way of being as much as to a way of working. I attempt in this paper to outline some of the aspects of Hillman's thinking which have made a particular impact on me, and argue that his ideas are highly original, intensely contemporary and deeply embedded in our "alternative" cultural history.

James Hillman may be 'one of the most imaginative thinkers of our time' (Casey, 1989: 233) or an eccentric scholar and analyst who has now descended to the status of pop psychologist. Time will tell how important he is in the greater scheme of things. I only wish to say that he has certainly been important to me. There are two or three books of which I can genuinely say that they changed my way of thinking - maybe even influenced my way of living. Revisioning Psychology (1975) is one of them.

I found reading that book in the late seventies a stimulating and frustrating experience. Stimulating, because it opened me up to a way of thinking which was new to me. Frustrating, because whenever I thought I was beginning to understand what Hillman was saying he would pull the mat from under me and make me start again. In reading Revisioning Psychology I learned something that had evaded me in my previous studies of Jung and the humanistic psychologists I was interested in: that how we think is more significant than what we think. In this context, the fact that what Hillman thinks has gone through some significant mutations in the past forty years does not bother me.

The impact of the sudden shift of perspective that came from my encounter with Revisioning Psychology has remained with me. I've read a lot of Hillman since. I don't find his writing as startling now, though perhaps I would if I were coming to it for the first time. Whatever Hillman's impact on others, I'll content myself for now in enumerating some of the ways his work has impacted on me and the reasons I am grateful to him. 


\section{Journal of Jungian Scholarly Studies 2}

Firstly, he led me to a polytheistic psychology. He took me beyond Jung's more cautiously pluralistic model of personality to a perspective in which the gods are foundational 'as cosmic perspectives in which the soul participates' (1975:169). And foundational not only in personality but in politics, economics, science, aesthetics and other expressions of culture. And he took me back to the place where I started (a childhood fascination with Greek mythology and the decision to study Classics at University) so that I could know it for the first time.

Hillman led me to read Corbin, and taught me to take imagination seriously and realise that everything we know we know as image. He took me past Freud's assertion of the prevalence, and inferiority, of mythical thinking, and past Jung's understanding that mythos is as valid a window on reality as logos. He turned the mythos-logos relation on its head, arguing that all thinking is essentially metaphorical, that the supposed 'facts' of science are images. He argued that what we regard as rational thought is but one form of mythical thought. And while making this categorical assertion, he acknowledged that this is itself - like all his other assertions - a fantasy!

Hillman made me aware of the tendency to literalism and reification to be found in my own thinking - and in much Jung-inspired writing. I noted his aversion to talking about 'the unconscious' and 'the soul' and 'the ego' as though they were 'things' existing in a world of 'things'. He led me to an understanding of soul as a perspective...' a viewpoint towards things rather than a thing in itself.' (ibid: $\mathrm{x}$ ).

He led me a little further on the same path to a point where I'm inclined to avoid talking about 'things' at all. David Ray Griffin, in Archetypal Process (1989) - a book to which Hillman makes a substantial contribution - argues that Jung's psychology does not match his cosmology very well. He suggests that Whitehead's process metaphysics provides a much better foundation for Jungian speculation and practice than the substance metaphysics which Jung seems to have taken for granted. I can thank Hillman for leading me by this somewhat indirect route to Whitehead's philosophy and the process psychology that emerges from it. I find it much more compatible with Jung-oriented work - academic and therapeutic - than the hydraulic model of the psyche which Jung inherited from Freud and the tradition of scientific materialism. It seems to me that in a lot of Jungian writing we can find the residue of a mechanistic world-view which from which Jung wished to extricate himself. Hillman has very effectively done this for himself and for readers who take him seriously.

I'm grateful to Hillman for again and again challenging my fantasy that now I've 'got it', for undermining my attempts to find clarification rather than live with ambiguity and paradox. I'm grateful for his intellectual subtlety, his eloquence, the poetry of his language. I respond to his urging to shift my focus away from my 


\section{Neville}

personal subjectivity and be prepared to find subjectivity more widely distributed in an ensouled universe.

Hillman teaches us that pathologizing is essential to the soul, that we all owe a debt of gratitude to our symptoms as the windows through which the gods force themselves into our awareness. Pathology, like everything else we experience, is archetypally constellated, and no event is without its shadow. He urges us to see through our symptoms, personal and cultural, to their archetypal originals - a far richer and more rewarding approach than engaging the heroic ego to do battle with them. In this context, I'm grateful to him personally for making me more comfortable with my own pathology.

Some years ago I published a paper (1992) in which I suggested that Hillman's thinking, like that of Jacques Lyotard (1981), offers both a manifestation of the peculiar intellectual sensibility known as 'the postmodern condition', and a way of analysing it. I suggested that this condition was neither 'modern' nor 'post' and that the ancient Greeks would have recognised in it the presence of Hermes. I observed that the culture of Europe and her colonies appeared to be currently in the grip of a 'Hermes inflation'. I argued that the presence of Hermes was manifest not only in the phenomena to which the analysts of postmodernity drew attention, but also in their own mode of thinking. I suggested that Hillman's writings, with their radical relativism, multi-perspectivism, de-throning of the heroic ego, subversion of the patriarchy, focus on image, complexification and constant self-deconstruction represented a postmodern psychology. It seemed to me that the twisting and turning, the slipperiness and sleight of hand, which characterize his writing give expression to Hermes the trickster and thief, just as their imaginative power and poetic beauty can be 'seen through' to Hermes the bringer of dreams and guide of souls.

It is conventional enough to suggest that Hillman is a postmodern thinker, or that his writing represents a Hermes consciousness. He has been happy enough to be categorised in this way -"Mars guides me more than Saturn, Hermes more than Athena'. (1989: 218) However, in his response to my paper he strenuously objected to being put in the same box as Foucault, Derrida, Lyotard and the rest, asserting that 'archetypal psychology is a psychology and not an exercise of the ironic French intellect.' (1999: 9). He argues that imagining is a better method for engaging the repressed than analyzing, that while archetypal psychology honours the image, the conceptual language of the poststructuralist philosophers fails it.

In labelling Hillman a postmodernist I was placing him among constructive postmodernists like Griffin and Kegan, rather than among the deconstructionists, with whom he has little sympathy. Nevertheless, I believe that, in the bigger 


\section{Journal of Jungian Scholarly Studies 4}

picture, Hillman does belong in the same box as Foucault and his fellows - though I admit that it is a pretty large box.

Since the eighties there has been significant historical analysis of the 'radical enlightenment', a cultural movement which originated in the seventeenth century and took a different trajectory both from the mainstream 'moderate enlightenment' and from Christian orthodoxy. (cf Jacob, 1981; Israel, 2001; Gare, 2005) Gare argues that the 'moderate' enlightenment which we associate with Locke and Newton represented the neutralisation of a much more radical movement which had evolved out of the Renaissance quest for liberty and democracy. The moderate enlightenment was grounded in belief in a clockwork universe supervised by a transcendent deity; in contrast the radical enlightenment did not separate Creator from creation - Nature simply is and everything that exists is part of this greater All.

Renaissance humanists such as Ficino and Giordano Bruno had shown how polytheistic symbolism could be used to undermine orthodoxy and Christian ethics and had espoused the naturalistic, vitalistic pantheism which the radicals inherited. Accordingly, Spinoza and other seventeenth century proponents of the radical enlightenment (who imagined themselves to be guided by both Mercury/Hermes and Athene/Minerva) were demonised as 'freethinkers', harassed and imprisoned by both Church and State, and variously labelled as pantheists, deists, pagans and atheists. Where the philosophers of the moderate enlightenment supported absolute political and religious authority, the radical philosophers sought to bring about democracy, tolerance, the liberation of women and the abolition of slavery. Where the moderate enlightenment proclaimed its newly-discovered ability to reach truth through propositional logic, the radical enlightenment embraced not only reason but myth, magic and emotion. The proponents of radical enlightenment certainly did not agree about everything, but they shared an approach to reality which respected the imagination and acknowledged the presence of soul in the world. We can argue with some justification that the postmodern loss of faith in progress represents the exhaustion and discrediting of the moderate enlightenment. (See MacIntyre, 1984, 51ff.) We can argue at the same time that Hillman's writings represent a postmodern revival of the radical enlightenment.

Hillman's writings are innovative indeed, but they have their roots in a radical tradition which goes back to the Renaissance and beyond, and they have a contemporary intellectual context. There is an arc of thought which runs from Ficino and Giordano Bruno, through Spinoza, Diderot, Vico, the romantic poets and the idealist philosophers, finds new voice in Whitehead, James, Bergson and Jung, and speaks to us now in the words of Hillman, the process philosophers, the creation theologians, the ecophilosophers, the deep ecologists, the 'new scientists' and even a few ironic French post-structuralists. Not all of them are pantheists or panexperientialists, not all of them have been passionate republicans or dedicated 


\section{Neville}

to the liberation of women and the abolition of slavery, not all of them take a polytheistic or multiperspectival approach to reality, not all of them argue vehemently that the cosmos is alive, not all of them take mystical experience seriously. Yet they have in common a rejection of scientific materialism and its mechanical universe, a distaste for hierarchical structures of power, and outrage at conventional science's devaluation of nature.

Unlike some of his contemporary companions in this tradition Hillman resists the seductions of psychological monotheism and brings both an aesthetic imagination and an ironic intellect to the task of expounding the importance of importance. In David Tacey's words: 'In a fierce backlash against a constructivist world which only believes in cultural inscriptions on the human body, Hillman writes in praise of such old-fashioned baggy monsters as destiny, fate, providence, calling, beauty, truth, vision, inspiration, genius, daimon.' (1998:221) It does not bother me to find Hillman in his more recent writings proposing an essentialism which his earlier thinking found intolerable, even in Jung. In the kind of universe I live in, every idea has its shadow, which must be acknowledged. Even physicists and process philosophers must occasionally interrupt their speculations on the insubstantiality of 'matter' if they wish to avoid being run over by a bus.

Monotheistic orthodoxy and scientific materialism (what remained of the moderate enlightenment after the notion of a transcendent spirit was found to be surplus to requirements) still hold centre stage. The tradition of radical enlightenment is still marginal and still precious. I've observed that many Jungian and Whiteheadian academics reluctantly accept marginality as their lot. Not Hillman. I find that, like his predecessors in the radical enlightenment, he approaches the world with passion. For the past couple of decades he has been arguing that we have no choice but to carry out both our scholarly and our therapeutic work in the context of the possibility of planetary catastrophe. Psychotherapy must move beyond individualism, beyond family and society and environment, to deal with the cosmos. 'Psychology', he says, 'needs to wake itself up to one of the most ancient human truths: we cannot be studied or cured apart from the planet.' (1995: xxii). I may well have arrived at this position without the assistance of Hillman, but I appreciate finding us in the same place.

I was deeply interested in Jungian thought before I encountered Hillman. It is, as my students assert, 'really rich stuff'. I'm grateful to him for making it richer. 


\section{Journal of Jungian Scholarly Studies 6}

\section{Works Cited}

Gare, Arran. "Reviving the radical enlightenment: process philosophy and the struggle for democracy." Paper presented at the 6th International Whitehead Conference, Salzburg, 3-6 July, 2006.

Griffin, David Ray. Archetypal Process: Self and the Divine in Whitehead, Jung and Hillman. Northwestern University Press, 1989.

Hillman, James. Revisioning Psychology. New York: Harper and Row, 1975.

Hillman, James. Archetypal Psychology. Dallas: Spring Publications, 1983.

Hillman, James. "Back to beyond: on cosmology." Archetypal Process: Self and the Divine in Whitehead, Jung and Hillman. Ed. David Ray Griffin. Evanston, ILL: Northwestern University Press, 1989. 213-232

Hillman, James. "A psyche the size of the earth". Ecopsychology: Restoring the Earth, Healing the Mind. Eds Theodore Roszak, Mary Gomes and Alan T. Kanner. San Francisco: Sierra Club Books. 1995.

Hillman, James. “A Note on Hermes Inflation.” Spring 65, (1999). 7-14.

Jacob, Margaret. The Radical Enlightenment: Pantheists, Freemasons and Republicans. London: George Allen \& Unwin. 1981.

Israel, Jonathan. Radical Enlightenment: Philosophy and the Making of Modernity $1650-1750$ Oxford University Press, 2001.

Kegan, R. In Over Our Heads: the Mental Demands of Modern Life. Cambridge, Mass: Harvard University Press, 1994.

Lyotard, Jacques. The Postmodern Condition. Manchester University Press, 1983.

MacIntyre, Alisdair (1984) After Virtue: A Study in Moral Theory. University of Notre Dame Press, 1984.

Neville, Bernie. "The Charm of Hermes: Hillman, Lyotard and the Postmodern Condition.” Journal of Analytical Psychology, July1992 337-353.

Tacey, David. ‘Anima to world soul: academia to pop.' Post-Jungians Today: Key Papers in Contemporary Analytical Psychology. Ed. Ann Casement. London: Routledge, 1998. 